Syntax Literate: Jurnal Ilmiah Indonesia p-ISSN: 2541-0849

e-ISSN: 2548-1398

Vol. 7, No. 1, Januari 2022

\title{
REKOMENDASI PEDOMAN PENCEGAHAN COVID-19 PADA KASUS SANGAT TERINFEKSI DI INDONESIA
}

\author{
Hafiyyan Dinan Ardiansyah, Nabilah Shafiyyah Rahmayati \\ Universitas Airlangga Surabaya, Indonesia \\ Email: hafiyyanmmbs@gmail.com,nabilahshafiyyah@ rocketmail.com
}

\begin{abstract}
Abstrak
Kasus pertama positif COVID-19 terkonfirmasi di Indonesia diumumkan langsung oleh Presiden RI, Bapak Joko Widodo. Dikatakannya, terdapat 2 WNI yang tertular virus Corona karena kontak pada 14 Februari 2020 di Jakarta. Kondisi saat ini perAgustus 2021 kasus positif yang terkonfirmasi di Indonesia mencapai jumlah 3,87 juta orang dengan jumlah meninggal dunia sebanyak 119 ribu orang. Vaksin sudah masuk ke Indonesia tetapi masih belum sepenuhnya didistribusikan untuk seluruh masyarakat. Selain vaksin tindakan pencegahan lainnya masih sangat dibutuhkan. Sehingga, bagi warga yang belum terpapar atau terinfeksi perlu lebih diperhatikan pencegahannya, tidak menimbulkan cluster baru dan penyebaran virus lebih luas. Berbagai strategi pencegahan dan intervensi non-obat merupakan kebutuhan bagi seluruh lapisan masyarakat yang nantinya bermanfaat bagi diri sendiri dan orang lain. Metode yang digunakan pada jurnal ini adalah mencari dan mengumpulkan data tentang COVID-19, preventif, kasus, dan lainnya. Hasil yang didapatkan adalah metode-metode preventif untuk COVID-19. Misalnya, pembatasan sosial skala besar, pemakaian masker, sering mencuci tangan, penggunaan sanitasi tangan, penggunaan disinfektan dan konsumsi makanan bergizi dan herbal. Semua tindakan tersebut akan berdampak besar pada berbagai aspek masyarakat. Kajian ini dirancang dengan tujuan utama merekomendasikan masyarakat terutama yang belum terpapar, untuk menghadapi pandemi ini dan dampak selanjutnya yang akan dibahas lebih lanjut dalam makalah ini.
\end{abstract}

Kata Kunci: covid-19; Indonesia; strategi pencegahan; restriksi sosial

\section{Abstract}

The first confirmed positive case of COVID-19 in Indonesia was announced directly by the President of the Republic of Indonesia, Joko Widodo. He said, there were 2 Indonesian citizens who positive with Corona virus due to contact on February 14, 2020 in Jakarta. The current condition as of August 2021 confirmed positive cases in Indonesia reached 3.87 million people with 119 thousand deaths. The vaccine has entered Indonesia but is still not fully distributed to the entire community. In addition to vaccines, other preventive measures are still very much needed. Various prevention strategies and non-drug interventions are a necessity for all levels of society which will benefit themselves and others. The method used in this journal is to find and collect data about COVID-19, prevention, cases, and others. The results obtained are methods of prevention for COVID-19. For

$\begin{array}{ll}\text { How to cite: } & \text { Hafiyyan Dinan Ardiansyah, Nabilah Shafiyyah Rahmayati (2022) Rekomendasi Pedoman Pencegahan Covid- } \\ & 19 \text { pada Kasus Sangat Terinfeksi di Indonesia. Syntax Literate: Jurnal Ilmiah Indonesia, } 7 \\ & \text { http://dx.doi.org/10.36418/ Syntax-Literate.v7i1.4124 }\end{array}$


example, social activities, use of masks, frequent hand washing, use of hand sanitation, use of disinfectants and consumption of nutritious and herbal foods. All of these actions will have a major impact on. various aspects of society. This study was designed with the main aim of recommending the public, especially those who have not been exposed, to deal with this pandemic and its subsequent impacts which will be discussed further in this paper.

Keywords: covid-19; Indonesia; prevention strategies; social restrictions

Received: 2021-12-20; Accepted: 2022-01-05; Published: 2022-01-15

\section{Pendahuluan}

COVID-19 berasal dari Wuhan, Hubei di China pada akhir Desember 2019. Setelahnya, virus ini telah menyebar di lebih dari 210 negara dan wilayah (OeyGardiner \& Abdullah, 2021). Merupakan penyakit yang menyerang sistem pernafasan dan disebarkan oleh Coronavirus 2 atau bisa disebut SARS-CoV-2 virus. Gejala pasien yang muncul menyerupai penyakit flu seperti, batuk kering, sakit tenggorokan, demam tinggi, anosmia dan masalah pernapasan lainnya. Penyakit yang disebabkan oleh SARSCoV-2 disebut COVID-19. COVID-19 ini dapat menular dari manusia ke manusia dengan cepat sehingga menjadi epidemi yang mengakibatkan krisis kesehatan global sampai saat ini. COVID-19, yang berasal dari zoonosis. Zoonosis adalah penyakit atau infeksi yang ditularkan oleh hewan pada manusia (Murdiati \& Sendow, 2006). Pandemi COVID-19 ditetapkan sebagai bencana global paling krusial dalam hal kesehatan dan juga merupakan tantangan terbesar yang dihadapi umat manusia sejak Perang Dunia 2. Akibat dari kondisi tersebut juga akan menghadirkan tantangan utama bagi sistem pelayanan kesehatan dan kebijakan kesehatan masyarakat yaitu diterapkan di seluruh dunia, karena memerlukan pengobatan baru dan strategi pencegahan untuk beradaptasi dengan efek pandemi ini.

Data WHO terbaru terkait COVID-19 terdapat lebih dari 208 juta orang yang terkonfirmasi dengan lebih dari 4 juta kasus kematian dengan jumlah kasus baru terus meningkat yaitu 105 ribu orang per-Agustus 2021 (WHO, 2020). Sementara di Indonesia terdapat 3,8 juta kasus yang terkonfirmasi dengan 119 ribu kasus kematian dan kasus baru sebanyak 17 ribu kasus. Penyebab tingginya angka kasus ini selain karena cepatnya penyebaran virus ini juga karena tingginya aktivitas dari aspek sosial, ekonomi dan agama di Indonesia. Dampak dari situasi ini adalah warga di Indonesia masih melanjutkan aktivitasnya seperti biasa. Tujuannya untuk kelangsungan aspek ekonomi bagi kehidupan mereka.

Akibat dari kegiatan ini, pemerintah membuat aturan normal baru. Berbagai strategi pencegahan dianjurkan dari pemerintah, terutama bagi warga yang belum terpapar dan yang belum tertular, seperti larangan sosial berskala besar, penggunaan sanitasi tangan, sering mencuci tangan, penggunaan disinfektan, mengonsumsi makanan bergizi dan vitamin yang berasal dari buah-buahan atau tanaman herbal, penggunaan 
masker dan alat pelindung diri, dan yang terakhir diberlakukan aturan karantina wilayah total jika diperlukan.

\section{Metode Penelitian}

Dalam jurnal ini penulis mencari dan mengumpulkan data tentang COVID-19, preventif, kasus, dan lainnya. Mesin pencari yang digunakan adalah Elsevier, Google Scholar, PubMed dan lain-lain. Istilah pencarian yang digunakan meliputi: coronavirus, COVID-19, manajemen pencegahan, pembatasan sosial. Tujuan jurnal ini adalah untuk membuat pedoman yang direkomendasikan untuk COVID-19 dari pendapat dan perspektif penulis.

\section{Hasil dan Pembahasan}

\section{A. Semua Tentang COVID-19 dan Transmisinya}

Kejadian awal wabah COVID-19 bermula ketika seorang pasien pneumonia diduga terinfeksi dan ada kaitannya dengan pasar ikan di kota Wuhan China pada akhir Desember 2019 (Zheng et al., 2020), yaitu pasar adalah perdagangan jual beli satwa liar dan eksotik seperti kelelawar, katak, ular, burung, trenggiling dan lain-lain. Virus SARS-CoV-2 berkaitan dengan pasar ini karena virus tersebut berasal dari kelelawar. Berdasarkan analisis filogenetik, total panjang genom SARS-COV-2 mirip dengan genom kelelawar SARS-CoV, 88\% identik, yang diasumsikan kemungkinan menjadi sumber utama virus COVID-19 (Mashuri, Delima, \& Rusny, 2020). Di sisi lain, terdapat beberapa penelitian yang menunjukkan adanya kemiripan pada genom SARS-CoV yang berasal dari trenggiling, 91\% identik.

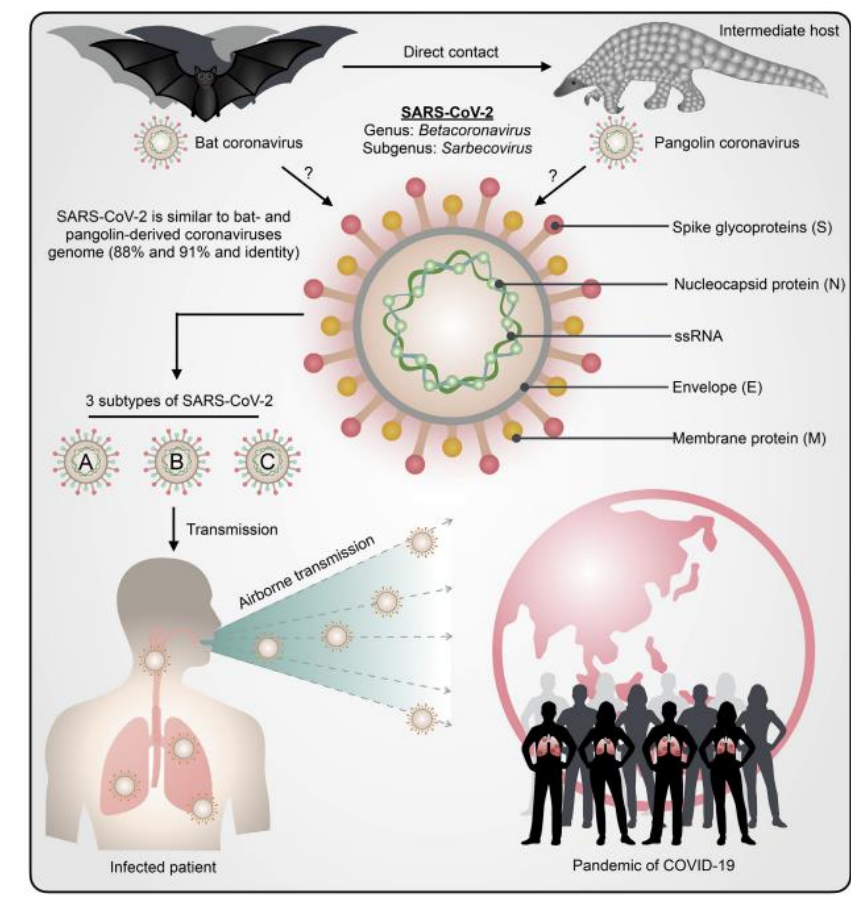

Gambar 1

Etiologi SARS-CoV-2 (Panyod, Ho, \& Sheen, 2020) 
Profil Coronavirus 2 ini sangat menular dan dapat ditularkan melalui droplet dan kontak dekat. Jenis penularan dari virus COVID-19 antara lain penularan aerosol dari manusia ke manusia, penularan virus terjadi karena kontak dekat dengan orang yang telah tertular dan terpapar seseorang akibat batuk, bersin, dan droplet cairan atau aerosol dari pernapasan. Aerosol dari respirasi ini dapat menembus tubuh manusia (sistem pernafasan) melalui penghirupan melalui hidung atau mulut (Phan, 2020); (Althaus, Probst, Hauser, \& Riou, 2020). Ada laporan bahwa Virus COVID19 dapat menginfeksi seseorang pada jarak sekitar 1,8 meter. Virus ini dapat bertahan selama 2 jam hingga beberapa hari sejak batuk dan bersin sehingga droplet cairan akan menempel pada permukaan benda atau tanah. Proses infeksi dimulai dari menyentuh benda atau permukaan yang terkena virus.

Model infeksi sel sangat mirip dengan SARS-CoV. Sasaran utama dari infeksi virus ini adalah paru-paru dan dapat menempel pada reseptor sel paru. (Hernaningsih, 2021) melaporkan bahwa pembelahan proteolitik yang terjadi pada protein SARS-CoV-S pada posisi (S2') memediasi fusi membran dan infektivitas virus. Spektrum klinis individu yang terinfeksi COVID-19 berkisar dari gejala ringan atau tidak spesifik hingga gejala penyakit pernapasan akut seperti demam, batuk, kelelahan, sesak napas, pneumonia, dan kegagalan sistem pernapasan yang sangat mirip dengan penyakit virus corona lainnya (Backer, Klinkenberg, \& Wallinga, 2020). Ada juga laporan dari pasien dewasa dan anak-anak yang terinfeksi COVID19. Data yang dikumpulkan dari tiga rangkaian kasus besar menunjukkan hasil sebagai berikut; Sebagian besar pasien dewasa menunjukkan gejala demam $(92,8 \%)$, batuk $(69,8 \%)$, kesulitan bernapas $(34,5 \%)$, mialgia $(27,7 \%)$, sakit kepala $(7,2 \%)$, diare $(6,1 \%)$, dan sakit tenggorokan $(5,1 \%)$. Di sisi lain, pada pasien anak, gejala yang muncul adalah demam, kelelahan, batuk, hidung tersumbat, pilek, diare dan sakit kepala. Saat virus menginfeksi, tanda-tanda lain seperti dispnea, sianosis, gejala sistemik yang terganggu lainnya termasuk malaise atau kegelisahan, nafsu makan yang buruk juga dapat muncul. Dalam keadaan yang parah, pasien yang lebih muda mungkin menunjukkan gagal napas.

\section{B. Dampak Wabah Covid 19 Dari Berbagai Aspek}

Banyaknya penderita yang mati akibat peristiwa pandemi ini juga berdampak besar terhadap kelangsungan hidup. COVID-19 telah mempengaruhi perekonomian secara global, termasuk Indonesia. Untuk membatasi dan mengurangi penyebaran virus secara luas di masyarakat, sebagian besar negara yang terkena dampak telah memutuskan untuk menerapkan pembatasan sosial skala besar. Penerbangan internasional dan domestik serta semua jenis transportasi bisnis telah dibatalkan. Karena batasan sosial, semua transportasi dibatasi atau dihentikan untuk sementara waktu kecuali transportasi untuk keperluan komoditas.

Pandemi COVID-19 telah melanda hampir seluruh negara di dunia termasuk Indonesia. Semua institusi pendidikan, komersial, olah raga dan spiritual atau keagamaan ditutup (Setiawan, 2020). Di sektor industri yang paling menderita karena 
banyak yang tutup atau dihentikan sementara akibat kejadian ini. Orang-orang yang bekerja di industri pariwisata dan transportasi juga menghadapi kesulitan. Laju produksi sudah sangat rendah. Perekonomian di negara berkembang saat ini menghadapi ancaman inflasi tinggi dan meningkatnya pengangguran akibat kurangnya angka produktivitas. Selain itu, lebih banyak pengeluaran akan digunakan untuk bantuan medis dan rehabilitasi korban COVID-19 dan keluarga pasien.

Indonesia menjadi sorotan di seluruh negeri terkait tingginya tingkat penularan COVID-19. Pemerintah mengatakan pandemi ini menyerang semua sektor, terutama sektor ekonomi. Banyak perusahaan di Indonesia mengandalkan sektor bisnis di sekitarnya, termasuk dari luar negeri. Pasalnya, perekonomian di Indonesia masih terkait dengan perekonomian global baik dari segi penawaran maupun permintaan. Data yang dikumpulkan di sektor industri mengalami penurunan sebesar 30\% diikuti oleh perdagangan yang turun sebesar $18 \%$ dan kemudian pertanian sebesar $11 \%$. Karena semua angka penurunan drastis dari beberapa sektor akan berdampak pada tenaga kerja di Indonesia. Sebanyak 3,8 juta pekerja di wilayah Indonesia telah terkena dampak ekonomi dan sosial dari pandemi ini.

\section{Strategi Tindakan Pencegahan}

COVID-19 masih menjadi ancaman global seperti halnya Indonesia sendiri, dimana setiap hari masih banyak kasus positif dan membutuhkan respon cepat yang melibatkan seluruh warga negara. Pemerintah harus bertanggung jawab dalam memberikan informasi yang akurat dan tegas untuk membantu warga menghadapi pandemi ini. Selain itu, warga juga harus mengikuti arahan dari pemerintah agar pandemi tidak menyebar. Untuk memutus mata rantai penyebaran COVID-19, beberapa strategi yang dapat menjadi pedoman bagi masyarakat Indonesia yang belum atau belum terpapar. Tujuannya untuk tindakan preventif agar tidak tertular dan kemungkinan angka konfirmasi kasus menurun.

\section{Batasan Sosial Skala Besar}

Hal pertama yang harus kita lakukan selama pandemi ini adalah membuat jarak aman. COVID-19 menyebar dan ditularkan dari orang ke orang melalui kontak langsung dan dekat. Dengan demikian, penyebaran penyakit pernafasan selama pertemuan massal merupakan masalah kesehatan masyarakat yang utama dengan potensi penyebaran penyakit menular ini. Kunci utama untuk mengurangi penyebaran COVID-19 adalah jarak sosial, yang bertujuan untuk mengurangi kemungkinan kontak antara orang yang terinfeksi dan orang lain yang tidak terinfeksi.

Penerapan aturan pembatasan sosial tersebut dapat menimbulkan masalah, terutama bila tindakan tersebut berdampak signifikan terhadap norma sosial, misalnya penduduk Indonesia sebagian besar adalah etnis Jawa, dimana budaya Jawa memiliki taraf sosial yang sangat tinggi. Contoh dari budaya ini adalah membuat mereka bersalaman saat bertemu kerabat, mengadakan arisan keluarga atau kerabat, serta acara atau kegiatan yang melibatkan banyak orang. Budaya ini dapat mempengaruhi jarak aman yang harus diterapkan. 
Selanjutnya dampak pada norma agama karena penduduk Indonesia memiliki agama yang beragam dan mayoritas adalah orang-orang yang taat pada agamanya, sehingga biasanya mereka melaksanakan ritual peribadatan di tempat ibadah masing-masing dengan melibatkan orang banyak. Terakhir, dampak terhadap aspek ekonomi yaitu penduduk Indonesia pada khususnya memiliki pekerjaan yang dituntut untuk dapat berinteraksi dengan orang lain.

Maka, langkah strategis yang direkomendasikan ini, yaitu pembatasan wilayah berskala besar yang akan memangkas penyebaran COVID-19 dan menurunkan angka kasus positif terkonfirmasi di wilayah Indonesia akan berdampak signifikan terhadap populasi. Memang strategi ini akan menimbulkan dilema bagi warga negara, namun langkah ini paling baik terutama bagi masyarakat yang belum tertular dan belum terpapar.

2. Penggunaan Disinfektan

Hal kedua yang harus dilakukan adalah menggunakan disinfektan dimanapun atau kapanpun dibutuhkan, terutama permukaan yang sering disentuh. Permukaan suatu benda merupakan tempat paling rawan penularan COVID-19, dari satu penularan ke penularan lainnya. Tergantung pada sifat permukaan, $\mathrm{pH}$, suhu dan kelembaban relatif lingkungan, variasi waktu persistensi virus ini dari 1-9 hari. Area permukaan yang berisiko tinggi terpapar atau terinfestasi virus ini harus sering dirawat dengan disinfektan terbaik. karakteristik disinfektan yang ideal adalah memiliki waktu kontak yang rendah dengan aktivitas antivirus yang signifikan.

Secara umum senyawa amonium, hidrogen peroksida, gugus alkohol (etanol, isopropil alkohol, fenol), aldehida, asam hipoklorit, asam sitrat konjugat dengan ion perak, natrium hipoklorit, natrium bikarbonat, dll merupakan bahan utama yang dapat merespon aktivitas virus. Kelompok alkohol, etanol (78-95\%) dan isopropanol (70-100\%) telah digunakan sebagai disinfektan yang efektif.

3. Penggunaan Sanitasi Tangan

Hal ketiga yang harus kita lakukan dalam pandemi ini adalah membawa sanitasi tangan kemanapun. Penularan dari manusia ke manusia adalah cara penularan utama dari wabah infeksi virus ini. Penularan COVID-19 ditularkan melalui droplet, batuk, kontaminasi tangan/permukaan, dll. Namun, pencegahan penularan dari orang ke orang dapat dikurangi dengan sering mencuci tangan dengan sabun dan air atau mendisinfeksi tangan dengan pembersih berbasis alkohol seperti yang direkomendasikan oleh WHO. Sebuah laporan dari WHO menunjukkan bahwa peningkatan penerapan praktik kebersihan tangan dapat mengurangi penularan hingga 50\%. Alkohol digunakan sebagai agen desinfektan yang umum dari zaman kuno. Sifat disinfektan potensial alkohol bergantung pada kekuatan dan jenis alkohol yang digunakan.

Namun di sisi lain, penggunaan sanitasi tangan yang mengandung racun secara terus menerus dan meningkat dapat mengakibatkan kematian; dapat dikonsumsi secara tidak sengaja, penyerapan melalui kontak kulit dan sebagai 
cara bunuh diri. Penggunaan sanitasi tangan berbahan dasar ethanol memiliki tingkat toksisitas sistemik yang minimal. Mirip dengan etanol, ISO-propil alkohol memiliki beberapa dampak negatif pada kesehatan manusia dan lingkungan. Sehingga masyarakat perlu cermat dan bijak dalam memilih sanitasi tangan.

Menurut rekomendasi WHO, Hidrogen peroksida dalam konsentrasi rendah aman bagi kesehatan manusia dan berdampak rendah terhadap lingkungan. Perlu diperhatikan kembali oleh warga, penggunaan sanitasi tangan pada anak harus diawasi oleh orang tua karena tingkat toksisitas sanitasi tangan pada anak cukup tinggi jika tertelan.

4. Penggunaan masker dan perlindungan pribadi lainnya

Pencegahan efektif lainnya dari penyebaran COVID-19 adalah penggunaan masker. Menurut WHO menjelaskan COVID-19 dapat ditularkan melalui udara, droplet (Nugroho et al., 2020). Penularan infeksi terjadi dalam jarak pendek 1 meter dengan seseorang didiagnosis sindrom pernafasan seperti batuk dan bersin. Droplet dengan diameter $>$ 5-10 mm berpotensi menempel pada mukosa mulut dan hidung kemudian menginvasi lapisan epitel saluran pernafasan bagian atas dan saluran cerna. Bukti penelitian telah menunjukkan dan melaporkan bahwa penggunaan masker pelindung dapat membantu mengurangi penularan tuberkulosis hingga 50\% dibandingkan pasien tanpa masker.

Penggunaan sarung tangan. Penularan melalui tangan yang terkontaminasi berkontribusi besar terhadap penyebaran infeksi COVID-19. Analisis menunjukkan bahwa frekuensi orang menyentuh wajah dan objek umum pada interval waktu rata-rata 3,6 dan 3,3 kali per jam. Penggunaan sarung tangan nitril lebih banyak diminati dibandingkan sarung tangan lateks karena tahan beberapa bahan kimia, termasuk disinfektan tertentu seperti klorin.

Penggunaan pelindung wajah. Adanya lendir di mata menjadikannya tempat yang bagus untuk kelangsungan hidup virus. Oleh karena itu, disarankan oleh WHO untuk menggunakan kaca pelindung transparan. Pelindung wajah yang baik dihasilkan dari bahan acetate, propionate, dan polycarbonate yang memiliki kejernihan visual serta kualitas optik yang baik.

5. Gizi seimbang pada masa pandemi

Kementerian Kesehatan RI mengeluarkan paduan gizi seimbang pada masa pandemic COVID-19. Makanan bergizi seimbang sangat penting agar dapat meningkatkan imun tubuh. Makanan yang dianjurkan untuk di makan berupa makanan pokok (sumber karbohidrat), lauk pauk (protein) serta sayuran dan buah (sumber vitamin, mineral dan serat). Anjuran lain dari pencegahan COVID-19 adalah mencuci sayur dan buah dengan bersih, memasak lauk dengan matang dan mengurangi gula serta garam.

Konsumsi vitamin, khususnya vitamin $\mathrm{C}$ merupakan salah satu intervensi farmakologis untuk COVID-19. Penelitian di Amerika Serikat menunjukkan bahwa pemberian vitamin $\mathrm{C}$ iV $15 \mathrm{~g}$ /hari seama 4 hari dapat menurunkan mortalitas komplikasi seperti ARDS dan syok pada pasien COVID-19 (Truwit et 
al., 2019). Selain itu, pemberian vitamin C oral (6 g/hari) dapat mengurangi risiko infeksi atau mengatasi gejala. Vitamin D juga membantu menguragi komplikasi terkait pneumonia dan badai sikokin darin infeksi COVID-19 (Khan et al., 2020).

Selain asupan bergizi seimbang, rutin berolahraga juga diperlukan untuk meningkatkan kekebalan tubuh dan sistem metabolisme. Istirahat yang cukup dan pikiran yang bahagia dapat menurunkan hormon stress tubuh sehingga dapat meningkatan metabolisme. Aktivitas fisik yang dianjurkan adalah sekurangkurangnya 30 menit secara rtin 3-5x seminggu.

6. Vaksinasi

Vaksinasi adalah proses di dalam tubuh, dimana seseorang menjadi kebal atau terlindungi dari suatu penyakit sehingga apabila suatu saat terpapar dengan penyakit tersebut maka tidak akan sakit atau hanya mengalami sakit ringan, biasanya dengan pemberian vaksin. Menurut WHO terdapat 13 vaksin yang dapat digunakan untuk pencegahan COVID-19. Contoh vaksin tersebut adalah Pfizer (sejak 31 Desember 2020), SII dan AstraZeneca (sejak 16 Februari), Janssen (sejak 12 Maret 2021). Selanjutnya ada Moderna (sejak April 2021), Sinoparm (7 May 2021) dan Sinovac (sejak 1 Juni 2021). Setelah vaksin terbukti aman dan efektif, vaksin harus disahkan oleh regulator nasional, diproduksi dengan standar yang ketat, dan didistribusikan. Per-9 September 2021 suda 70 juta orang mendapatkan vaksinasi ke-1 dan 40juta orang sudah vaksinasi ke-2 dari target sasaran 208 juta orang.

Vaksinasi dapat menghasilkan perlindungan terhadap penyakit dari hasil pengembangan respon imun terhaadap virus COVID-19. Vaksinasi merupakan langkah pengurangan risiko dari penyakit COVID-19 dan melawan virus jika terpapar. Vaksinasi juga dapat melindungi orang-orang di sekitar, karena jika terlindungi dari infeksi dan penyakit dapat tidak menulari orang lain. Hal ini sangat penting untuk melindungi orang-orang yang berisiko tinggi terkena penyakit parah akibat COVID-19, seperti tenaga kesehatan, orang dewasa yang lebih tua atau lanjut usia, dan orang-orang dengan kondisi medis lainnya.

Vaksinasi merupakan pencegahan agar tidak memiliki gejala yang lebih parah dan kematian. Vaksinasi bukan obat yang jika diminum akan menghilangkan COVID-19. Selama 14 hari pertama, perlindungan dari vaksin masih belum signifikan dan akan meningkat secara bertahap.

\section{Kesimpulan}

Pandemi ini berdampak pada kelangsungan hidup manusia di dunia ini. Tidak hanya sektor ekonomi, semua sektor seperti transportasi, olah raga dan lain-lain terkena imbas negatif dari pandemi ini. COVID-19, karena saat ini menyebar dan sangat berbahaya maka perlu perlindungan lebih dari itu. Perlindungan diri seperti menjaga jarak, penggunaan masker, sanitasi tangan dan pelindung lainnya sangat perlu dilakukan agar jumlah penularan COVID-19 tidak bertambah. Hal yang perlu dilakukan adalah melakukan tindakan pencegahan dan perlindungan diri jika memang perlu keluar 
Hafiyyan Dinan Ardiansyah, Nabilah Shafiyyah Rahmayati

rumah. Pemilihan bahan yang tepat untuk sanitasi tangan dan disinfektan sangat diperlukan. Ketepatan dalam penggunaan sanitasi tangan dan desinfektan perlu diperhatikan agar tidak membahayakan tubuh manusia. Bekerja di rumah atau mengurangi frekuensi pertemuan dengan orang banyak juga sangat membantu mengurangi tingkat penularan COVID-19 ini. Seperti yang dijelaskan di jurnal ini, jika harus keluar rumah, gunakan pelindung diri dan perhatikan protokol kesehatan yang direkomendasikan oleh pemerintah, tetap waspada dan hati-hati untuk diri sendiri dan orang-orang di sekitar. 


\section{BIBLIOGRAFI}

Althaus, Christian L., Probst, Daniel, Hauser, Anthony, \& Riou, Julien L. (2020). Time is of the essence: containment of the SARS-CoV-2 epidemic in Switzerland from February to May 2020. MedRxiv. Google Scholar

Backer, Jantien A., Klinkenberg, Don, \& Wallinga, Jacco. (2020). Incubation period of 2019 novel coronavirus (2019-nCoV) infections among travellers from Wuhan, China, 20-28 January 2020. Eurosurveillance, 25(5), 2000062. Google Scholar

Hernaningsih, Yetti. (2021). Aspek Laboratorium Covid-19. Airlangga University Press. Google Scholar

Khan, Shahzar, Faisal, Shah, Jan, H., Usman, Hazrat, Zainab, Rimsha, Taj, Faqeer, Amrani, Rahma, \& Tayyeb, Muhammad. (2020). COVID-19: a brief overview on the role of vitamins specifically vitamin $\mathrm{C}$ as immune modulators and in prevention and treatment of SARS-Cov-2 infections. Biomed J Sci Tech Res, 28(3), 21580-21586. Google Scholar

Mashuri, Masri, Delima, Enggar Mareth, \& Rusny, Rusny. (2020). Turnitin Buku: Everything About Corona Mulai dari Sejarah, Genom virus SARS-COV-2, analisis filogenetik, Mutasi Virus, Keragaman Genetik, Epidemiologi COVID 19, Sumber Infeksi, Faktor Risiko, Karakteristik Klinis, daftar obat, sampai tindakan pencegahan penyebaran virus SARS-CoV-2. Dr. Alauddin University Press. Google Scholar

Murdiati, Tri Budhi, \& Sendow, Indrawati. (2006). Zoonosis yang ditularkan melalui pangan. Wartazoa, 16(1), 14-20. Google Scholar

Nugroho, Wahyu Dwi, Cahyani, Wulandari Indah, Tobing, Alanish Shahnia, Istiqomah, Nur, Cahyasari, Intan, Indrastuti, Murdewi, Sugondo, Priyo, \& Isworo, Atyanti. (2020). Literature Review: Transmisi Covid-19 dari Manusia ke Manusia di Asia. Journal of Bionursing, 2(2), 101-112. Google Scholar

Oey-Gardiner, Mayling, \& Abdullah, M. Amin. (2021). Ragam Perspektif Dampak Covid-19. Yayasan Pustaka Obor Indonesia. Google Scholar

Panyod, Suraphan, Ho, Chi Tang, \& Sheen, Lee Yan. (2020). Dietary therapy and herbal medicine for COVID-19 prevention: A review and perspective. Journal of Traditional and Complementary Medicine, 10(4), 420-427. Google Scholar

Phan, Tung. (2020). Genetic diversity and evolution of SARS-CoV-2. Infection, Genetics and Evolution, 81, 104260. Google Scholar

Setiawan, Heri Cahyo Bagus. (2020). Redesign Bisnis Pasca Pandemi Covid-19: Prespektif UMKM, BUMDes \& Usaha Ekonomi Pesantren. Mukmin Publishing. Google Scholar 
Truwit, Jonathon D., Hite, R. Duncan, Morris, Peter E., DeWilde, Christine, Priday, Anna, Fisher, Bernard, Thacker, Leroy R., Natarajan, Ramesh, Brophy, Donald F., \& Sculthorpe, Robin. (2019). Effect of vitamin C infusion on organ failure and biomarkers of inflammation and vascular injury in patients with sepsis and severe acute respiratory failure: the CITRIS-ALI randomized clinical trial. Jama, 322(13), 1261-1270. Google Scholar

WHO. (2020). WHO Coronavirus Disease.

Zheng, Changcheng, Wang, Jinquan, Guo, Hui, Lu, Zhaohui, Ma, Yan, Zhu, Yuyou, Xia, Daqing, Wang, Yinzhong, He, Hongliang, \& Zhou, Jian. (2020). Risk-adapted treatment strategy for COVID-19 patients. International Journal of Infectious Diseases, 94, 74-77. Google Scholar

\section{Copyright holder:}

Hafiyyan Dinan Ardiansyah, Nabilah Shafiyyah Rahmayati (2022)

\section{First publication right:}

Syntax Literate: Jurnal Ilmiah Indonesia

This article is licensed under:

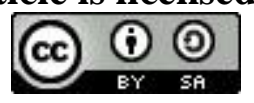

